\title{
IMPROVING COMMUNITY LITERATION THROUGH READING CORNER
}

\author{
Winda Widyanty \\ Faculty of Economics and Business, Mercu Buana University \\ winda.widyanty@mercubuana.ac.id
}

\begin{abstract}
Based on the survey released by the UNESCO in 2017, Indonesia was ranked 60th out of 61 countries on reading interest. This result is in line with the findings of the preliminary survey conducted by a community dedication team in South Meruya district. They find that reading interest in the area is very low indicated by the number of books read. The low reading interest could cause a negative impact, especially in a digital era where any information can be accessed through social media. Unfortunately, such information cannot be justified and is more often to provoke and causing chaos. Therefore, community service is held in Meruya Selatan district in order to increase the community literacy. The purpose is done by making a reading corner which aims to provide the community access to interesting and useful reading materials to increase reading interest and knowledge to create a high-quality community life.
\end{abstract}

Keywords: reading interest, community literation, reading corner, community empowerment.

\section{Introduction}

In 2016, UNESCO released a survey regarding reading interest in 61 countries which showed that Indonesia was ranked number 60 . The survey also revealed that the reading interest of Indonesian people was only $0.001 \%$. It means that only 1 out of 1,000 people who has a reading interest. There are five variables used by UNESCO - as stated in a book entitled World Literacy: How Countries Rank and Why It Matters published by Central Connecticut State University - namely libraries, newspapers, education systems (input), education systems (output), and computer availability. The low reading interest as showed in the UNESCO survey, among others, was influenced by the low distribution of books, the access to the book itself and the literacy of the society that could be one of the determinants of high reading interest.

Furthermore, data from Central Bureau of Statistics in 2016 showed that the percentage of illiterate in Indonesia was $17.09 \%$. People aged 45 years and over become the highest contributor with a percentage of $11.47 \%$. Meanwhile, illiterate people aged $15-44$ years contributed $4.62 \%$. This is not much different from 2015 , which was $17.77 \%$. Based on the data above, the making of reading corners as libraries and places for learning to read and write is important.

South Meruya Administrative Village is located in Kembangan sub-district, West Jakarta Municipality which covers an area of 360 ha with population of 35,639 people; 10,822 householder; 11 community groups and 84 neighborhood groups. This village belongs to one of urban areas with a hightech lifestyle. High density of housing and relatively narrow space may lead to many obstacles related to the activities of children, adolescents and parents in doing educative recreational activities such as reading in the library. Almost all information can be accessed publicly through gadgets and social media. The problems are getting more complex as social media is filled with interesting but not constructive things, such as hoaxes and other fake news that widely spread in the society through social media.

The purpose of implementing community empowerment through the creation of reading corners is to provide easy access to the community, especially in the South Meruya Administrative Village to obtain useful reading material for improving the ability and knowledge to support the life of the community itself. Moreover, reading corners can play a role to improve reading interest and to develope reading culture in the society. 


\section{Theoritical Review}

Ministry of Education and Culture (2016) defined literacy as the ability to access, to understand, and to use things intelligently through various activities, including reading, seeing, listening, writing, and speaking. Adya (2003) stated that literacy is literacy. Literacy is the foundation for lifelong learning activities which is very important for social development in order to improve the ability to change into a better life.

In the meantime, reading interest means a disposition that encourages individuals to seek opportunities and resources to carry out reading activities (Dewi, 2010). Hidi (2001) described two methods to examine one's interest in reading. First, someone who is interested in reading activities has a great desire to read when faced with a book. Second, someone whose interest in reading is influenced by situational factors such as book genre, individual processes and memory, visual stimulation such as images or objects being seen, auditory stimulation such as having heard conversations about reading, or a combination of visual and auditory. To improve literacy skills, a good reading interest is needed from the society.

Siswati (2010) explained some factors that influence reading interest. The first factor is the characteristics of the text. In many studies, reading characteristics will make reading activities more interesting. Next, the changing of certain aspects in the learning environment. This element is related to the way the text is presented, the material that is used to teach it and the self-regulation of the reader.

The concept of a reading corner is taken from the concept of Taman Baca Masyarakat (TBM), an institution that provides various types of learning materials needed by the community as a place to develop literacy and learning, as well as to get information for the public (Ministry of Education, 2008). The reading corner acts as a place that can be used as a source of information for local residents who are expected to motivate others to read and to grow interest in reading for the surrounding community by providing interesting reading materials to improve some insights and knowledge of the society.

In fulfilling its role as a learning resource to facilitate lifelong learning, the reading corner has a function as a place of learning and seeking information needed by the community. Referring to the guidelines for the management of community reading rooms, the reading corner which is part of the reading place has several functions including (1) learning facilities for the community to learn independently, and as a support for the curriculum for non-formal education programs, (2) sources of information from books and other reading materials that are suitable for the needs of the learning community and the local community, (3) research sources by providing books and other reading materials in literature studies, (4) reference sources, (5) entertainment sources that provide reading material to spend leisure time to get some new and interesting knowledge or information.

\section{Implementation Method}

Community service conducted in South Meruya Administrative Village consists of several stages, namely: (1) Preparation stage, (2) Implementation stage, and (3) Final stage. During the preparation stage, the researcher made a visit to South Meruya Administrative Village as a partner for observation regarding the collaboration that could be carried out by both parties. The first meeting was held with the village secretary who represented the head of South Meruya Administrative Village to discuss plans for collaborative activities by both parties. From the results of the first meeting, it was concluded that the partners needed a reading corner in the South Meruya Administrative Village as a supporting means of service to the community. It was agreed that the team from Mercu Buana University was willing to help to build reading corners as a form of community service. After the agreement was agreed upon the collaboration by both parties to build a reading corner, the next stage is to prepare procurement and equipment techniques including bookshelves, various types of reading books, book buffers, carpets and banners. 
Picture 1. Collaboration with South Meruya Administrative Village

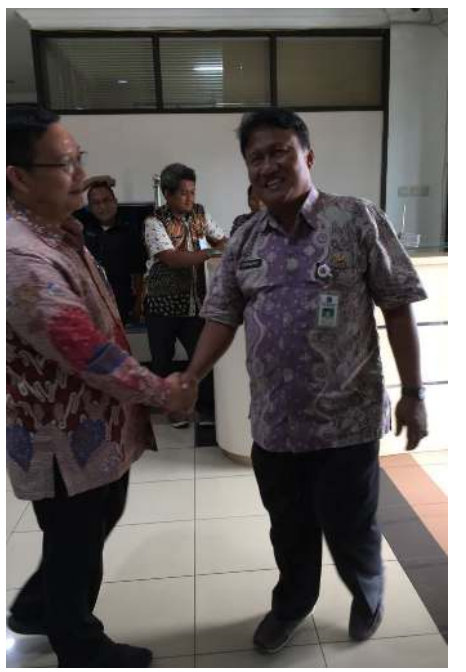

The next stage is the implementation stage. At this stage, the activity carried out is to design the bookshelves based on the shape and size of the room prepared for a reading corner in the South Meruya Administrative Village office. After that, the equipment was prepared to build reading corners such as books, bookshelves, and all the necessary equipment.

Picture 2. Bookshelf Design

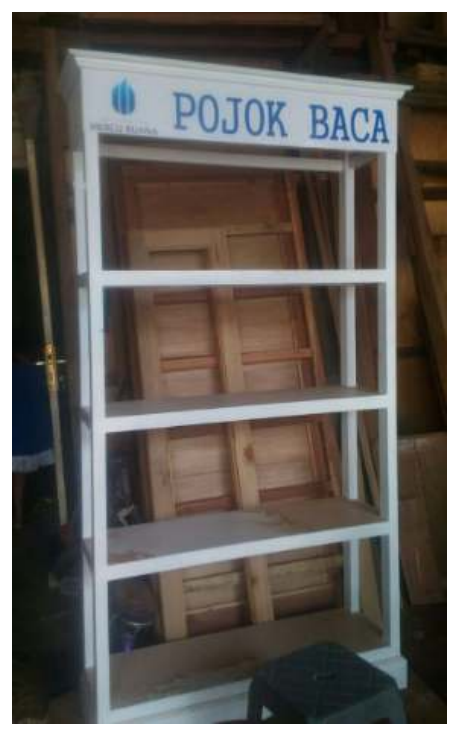


Picture 3. Shipping Process of All Equipment
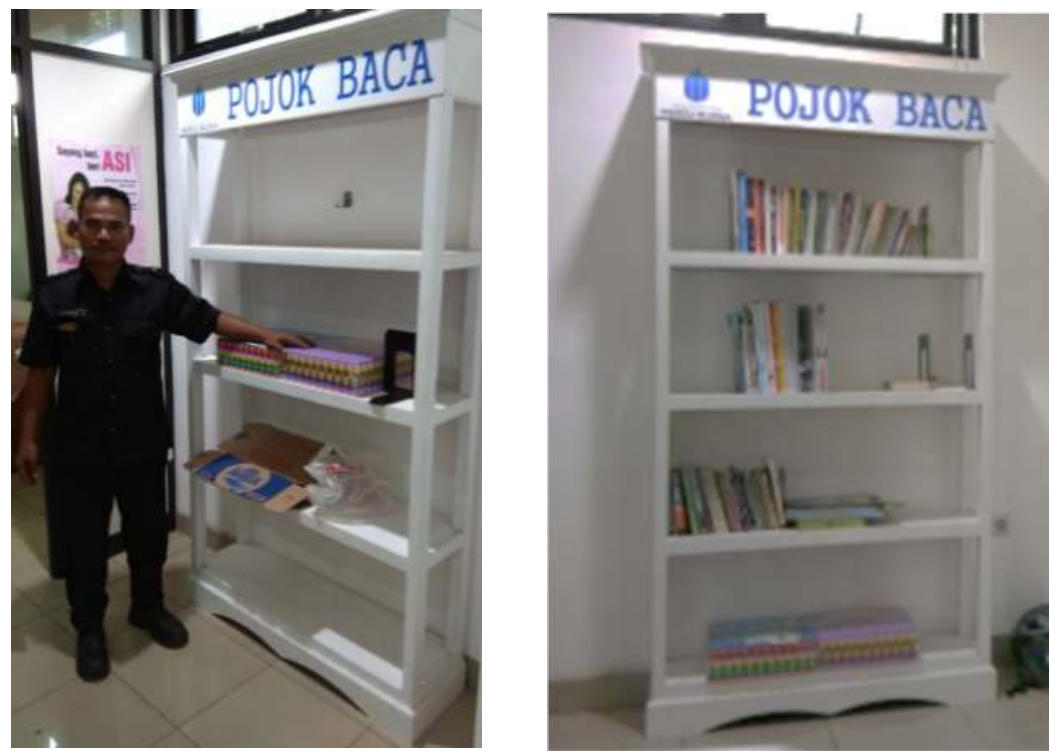

The final stage is the handover and the formal ceremony for the reading corner from UMB PPM Team to South Meruya Administrative Village and the socialization of the importance of the reading corner to improve public literacy.

Picture 4. Handover of Reading Corner

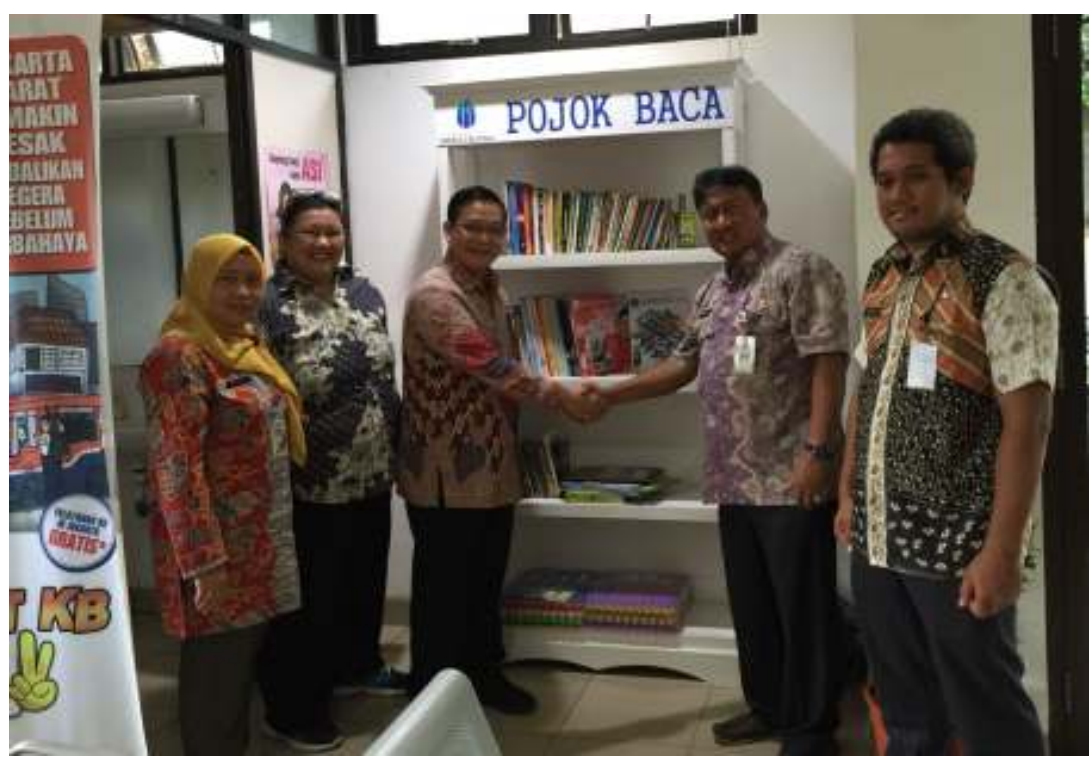


Picture 5. Formal Ceremony of Reading Corner

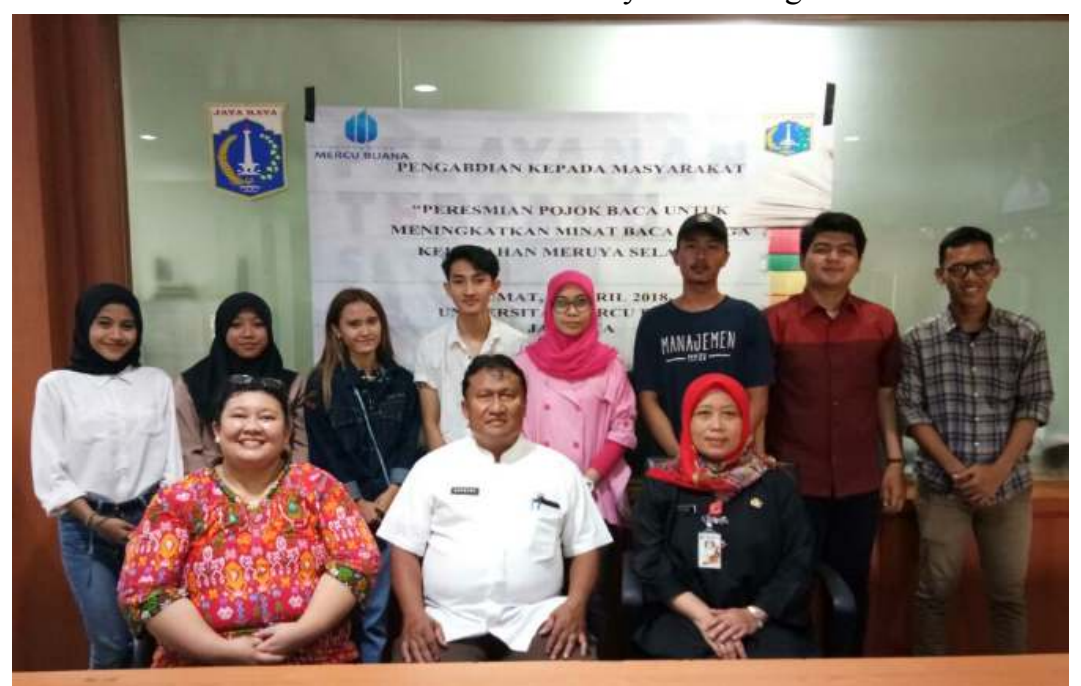

Picture 6. Utilization of Reading Corner by Residents

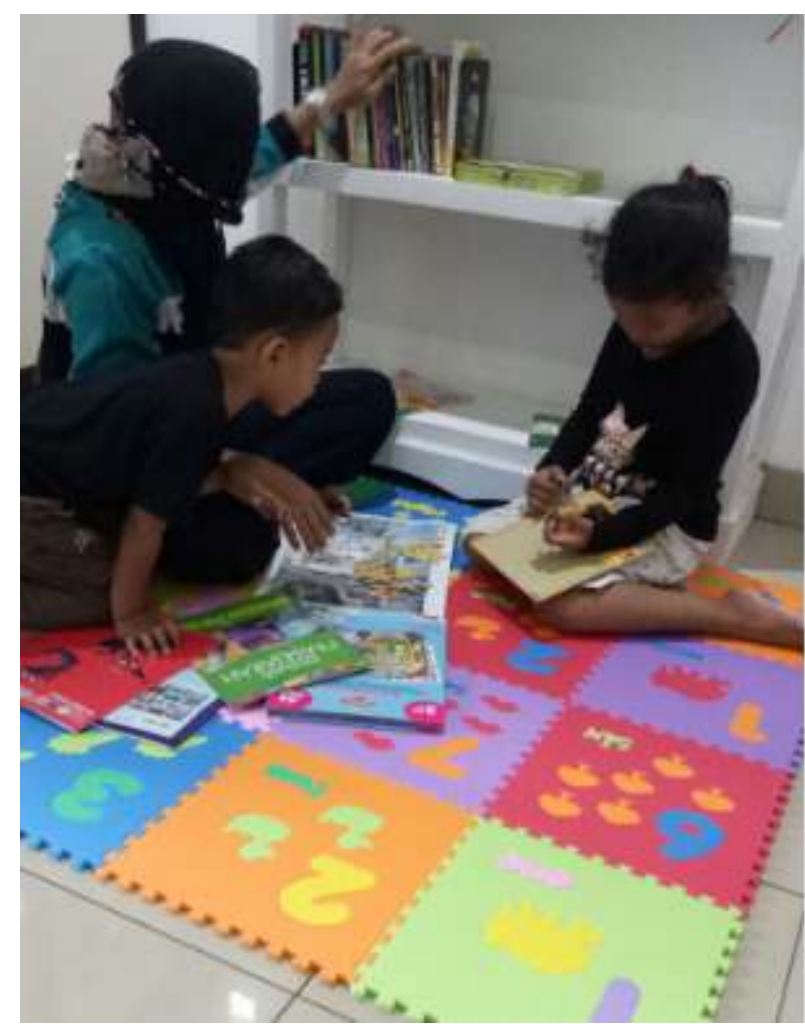

\section{Conclusion}

Indonesia still has low reading interest compared to other Asian countries. Local government has made various efforts to improve literacy within the community. Community empowerment programs by Mercu Buana University contributed to improve community literacy, especially in South Meruya Administrative Village through the creation of reading corners to develop interest in reading for local residents to improve their literacy skills. 


\section{Bibliography}

Adya, A. B. (2003). Dasar Dasar Pelayanan Prima Persiapan Membangun Budaya Pelayanan Untuk Meningkatkan Kepuasan dan Loyalitas Pelanggan. Jakarta: PT. Elex Media Komputindo.

Departemen Pendidikan Nasional, 2008. Naskah Akademik Pengelola Taman Bacaan Masyarakat (TBM). Direktorat Jenderal Peningkatan Mutu Pendidik dan Tenaga Kependidikan, Jakarta.

Dewi, C.R., 2010. Peran serta Taman Bacaan Masyarakat sebagai Modal Terwujudnya Surabaya sebagai Kota baca Memasuki Era Globalisasi. Direktorat Pendidik dan Tenaga Kependidikan Nonformal, Jakarta

Fuller, Danielle, and DeNel Rehberg Sedo. 2014. "And Then We Went to the Brewery": Reading as a Social Activity in a Digital Era." World Literature Today. Norman, OK: World Literature Today, MayAugust.

Hidi, 2001. Interest, Reading, and Learning: Theoritical and Practical Consideration. Educ. Psychol. Rev. 13.

Holik, Abdul. (2013). Peran Taman Bacaan Masyarakat (TBM) Sudut Baca Soreang dalam Meningkatkan Minat Baca Masyarakat di Kabupaten Bandung. Jurnal Pengabdian Masyarakat. Vol. 3, No. 1.

Siswati, 2010. minat membaca pada mahasiswa (Studi Deskriptif pada Mahasiswa Fakultas Psikologi UNDIP Semester I). J. Psikol. Undip 8.

UNESCO. 2014. Reading in the Mobile era: A Study of Mobile Reading inDeveloping Countries. Study Report in Education Sector, Paris: Unesco.

Verma, Jyoti, and Sharad Kumar Sonkar. 2013. "Impact of E-Resources and Web Technology on Reading Habits." In Challenges of Academic Library Management in Developing Countries, by S. Thanuskodi, 68-74. USA: IGI Global.

Wibowo, Wahyu. 2015. Kebiasaan Membaca Buku Masyarakat Indonesia Rendah. (online) tersedia:http://rri.co.id/post/berita/213647/nasional/kebiasaan_membaca_buku_masyarakat_indo n esia_rendah.html. (2 Agustus 2018) 